\title{
A PARODY OF PSALM 8 IN JOB 7:17-19
}

\author{
Bernadus Dirgaprimawan ${ }^{a, 1}$ \\ a Universitas Sanata Dharma, Yogyakarta, Indonesia \\ 1.dirgaprimawan@yahoo.com
}

\begin{abstract}
The book of Job presents us with a shocking story of a righteous man. He does everything what the Law says. Yet, he suffers. He looks for the answer of his suffering and finds nothing satisfactory. Uniquely, in chapter 7, the protagonist laments. The form of his lamentation somehow reminds its readers a poem similar to Psalm 8. However, there is a big contrast. Psalm 8 is a joyful hymn. Psalm 8 expresses man's confidence in God's faithful love. Yet, Job 7 contains a distress of man who experiences God as a cruel watchman. He feels that his life is completely under God's surveillance that makes him suffocated. Based on its literary genre, Job 7 is considered as a parody. Parody works by adapting a previously popular literary work into a new one, but with different intentions. In this paper, the intention of Job's author is going to be examined. Through the short analysis of its literary form, what can be found is that the author of Job 7 purposefully conveys a sharp criticism to the general notion of the Wisdom Tradition of that era. The Wisdom Tradition emphasizes much on the faith in God based on the relation between punishment and reward. This emphasis has reduced the complexity of human suffering.
\end{abstract}

\section{INTRODUCTION}

In the book of Job chapter 6 and 7, the protagonist expresses his agony. He laments loudly. He pleads for death and longs for a place that he might escape from God. ${ }^{8} \mathrm{O}$ that I might have my request, and that God would grant my desire; ${ }^{9}$ that it would please God to crush me, that he would let loose his hand and cut me off! ${ }^{10}$ This would be my consolation... (Job 6:8-10)." Furthermore, in response to Eliphaz's exhortation to make petition to God (5:8), with the prospect of a 'happy ending' (5:17-26), Job surprisingly, addresses God harshly. He blames God for his 'bad fate'. Job sends his expostulation to God.

How the author of the book presents Job's weariness and anger in chapter 6-7 is really shocking for many readers. In the early chapters of the book, Job is always presented as a righteous man of God, a faithful man to God. He does not open his mouth even when his friends comment on his 'bad fate'. Yet, what we find in chapter 6 and 7 is rather different. Job reacts. Job speaks of his weariness and frustration in anger. Furthermore, the author presents Job's lamentation in a poetic manner. Chapter 6-7 is structured into two alphabetical poems (acrostics with 22/23 lines). ${ }^{1}$

In this paper, I would like to limit myself only to a small study of Job 7:17-19 since these three verses as one strophe ${ }^{2}$ are fascinating. In order to distinguish between Job as a book and Job as the protagonist, in this paper, I will use an italic form when Job as a book is referred to. By looking at this strophe closely, the text itself (Job 7:17-19) gives an allusion to Psalm 8:5-6. The author presents it ironically. Psalm 8 is a happy psalm, a 
thanksgiving psalm. The Psalmist adores God for His concern for man's life. Yet, Job 7:17-19 gives a contradicting nuance. Job is in despair. Job is in his protest. He is not in the mood to adore God. How and why the author deliberately choose this text (Job 7:17-19) and present it ironically is what I am going to analyze. In a simple expression, questions will be; what do we find unique in Job 7:17-19? What kind of literary device that the author employs here? What is his purpose? Responding to these questions, my approach will be on the form-critical analysis of Job 7:17-19. My emphasis mainly will be based on the work of Katherine J. Dell in her 2013 book titled "Job, where shall wisdom be found?", the work of David Clines in one of the series of Word Biblical Commentaries, and also the work of Gray and Clines in "The Book of Job". My main argument is that the author knows very well Psalm 8. He intentionally imitates its form and content in order to instill a new message to the reader, a message of protest to the inadequacy of Hebrew wisdom tradition at that time.

\section{LITERARY STRUCTURE (UNIT)}

\begin{tabular}{|l|c|}
\hline \multicolumn{1}{|c|}{ Psalm 8:4-5 (NRSV) } & Job 7:17-19 (NRSV) \\
\hline${ }^{4}$ what are human beings & ${ }^{17}$ What are human beings, \\
that you are mindful of them, & that you make so much of them, \\
mortals that you care for them? & that you set your mind on them, \\
5 Yet you have made them & $\begin{array}{c}18 \text { visit them every morning, } \\
\text { a little lower than God, } \\
\text { and crowned them with glory and honor. }\end{array}$ \\
& ${ }^{19}$ Will you not look away from me for a while, \\
& let me alone until I swallow my spittle? \\
\hline
\end{tabular}

In order to highlight the uniqueness of Job chapter 7:17-19, a wider context of these verses will be presented. Therefore, in this section, I would like to describe briefly some characteristics found in Chapter 7 in relation to its closer chapter (Ch. 6), to the whole book, and to the other wisdom writings in general.

\section{The Uniqueness of the Book of Job with regards to Proverbs and Ecclesiastes}

As we commonly know, the book of Job is included in the third part of the Old Testament canon (the Writings). It is placed after Proverbs and Ecclesiastes. Unlike Proverbs, the book of Job focuses on a single theme, namely, a man's reaction to unmerited suffering. Regarding this single theme, Gray briefly comments, "...the problem of Job is the paradox of a man created in the image of God, tried beyond endurance yet not allowed to understand the reason or purpose of his suffering or to enjoy the relief of death he so earnestly desired..."3 I am underlining the word 'paradox'. By saying a paradox, Gray probably reminds us of two contradictory (opposing) ideas that we might often find in the book. As we are going to discuss later, Job
7:17-19 also shows us a paradox. There is a contradictory perception of a picture of God's loving care in Psalm 8 and of God's intimidating act in Job 7:17. In the book of Job, Gray emphasizes human experience as the heart of the paradox. For him, on the basis of experience, the author of Job questions the predominating wisdom tradition, exposing its inadequacy in ruthless dialectic. Gray states, "to hymns of praise extolling God's order in nature and society, Job opposes hymns of praise emphasizing the destructive aspect of the rule of God."

We may also compare the book of Job with Ecclesiastes in order to see its uniqueness. Unlike Ecclesiastes, "Job is not the reflection of lectures in the schools in spite of the form of sapiential controversy in which much of the book is cast", says Gray. ${ }^{5}$ Most likely Gray wants to emphasize on the free style that the author employs, rather than on a rigid form as commonly employed in wisdom schools at that time. In fact, the book of $J o b$ is quite confusing to read. What we find there is a mixed combination between narrative stories and poems, between monologues and dialogues, between sapiential texts and lamentations. Thus, Job is complex 
and controversial compared to other writings in the Old Testament. Yet, according to Whybray, the form and the content of the book of Job is designed to undermine a current dogma and to offer a rational defense of a revolutionary thesis. ${ }^{6}$ It seems that the author serves readers best by challenging them to confront their own reality, an unimaginable suffering.

\section{The Uniqueness of Chapter 7 in the Book of Job}

\section{Sapiential Text}

As mentioned in the introduction, chapter 7 focuses on Job's expostulation to God. Job doesn't listen to Eliphaz's suggestion. Here, chapter 7 contains two sapiential texts, with significant adaptation. According to Gray, the first sapiential text recalls Hezekiah's prayer in Isa. 38.10-18. Hezekiah recites his suffering with the grim prospect of Sheol (Isa 38.10). Yet, Hezekiah's prayer is a prelude to the hope of survival. It is distinct from Job 7, where Sheol is the culmination of Job's sufferings $(7.8,10,21){ }^{7}$ The second one is chapter 7.17 , with an allusion to Psalm 8:5. The psalmist asks "What are human beings?" Psalm 8 portrays man as physically so insignificant in the universe. However, God willingly pays him special attention as the apex of creation. ${ }^{8}$ Then, with mortals' limitations in mind, Job asks the same question. Here is the irony, "Why should God sustain and promote them simply to subject them to inquisition and torment?"9

\section{Acrostic Poem and Metaphor}

According to Perdue, Job's response to Eliphaz is a disputation composed of two alphabetizing poems $(6.2-23=22$ lines; and 6.28-7.21 = 23 lines).${ }^{10}$ Both poems are enriched by the use of metaphor. In the first poem, God is depicted as the Divine Warrior. Here, Job takes up Eliphaz' proposal to present his case before God, for adjudication by denouncing the justice of God and accusing the comforters of being fair-weather friends. Job characterizes God as the Divine Warrior whose arrows have pierced his body. In the second poem (7.1-21), Job and human beings are depicted as slaves to God. ${ }^{11}$ God is the king. There is an anthropological metaphor employed here. Perdue argues, “...Job poignantly depicts human existence in terms of a mistreated, miserable slave and as breath that quickly vanishes. And in a parody of Psalm 8 which extols God's exaltation of humanity to the position of king over creation, Job (the suffering and embittered slave) accuses God of singling him out for malicious attack..."12

\section{Monologue and Dialogue}

According to Clines, the structure (chapter 6-7) is divided into three parts, based on the directions in which Job turns his address. ${ }^{13}$ The first part (6:2-13) is a monologue. Job neither speaks to his friends nor God. He does not pay attention to his friends. Even when he speak of God, he places God in the third person. The second part (6:14-30) is a sort of dialogue. Here, Job clearly addresses himself to his friends. Even though in vv 14-22, Job's friends are in the second person, there is no doubt that these lines are directed to them. In v.21, his friends are identified as the treacherous friends. Until the end of the chapter, Job's friends are directly addressed in each verse, except in $\mathrm{v} 30$.

Contrary to the first and second parts, Clines mentions that the third (7:1-21) is wholly directed toward God. He says, “.... although vv 1-6 do not explicitly state the addressee, the imperative "remember" of $\mathrm{v} 7$, unquestionably directed to God, makes clear that vv 1-6 have been for his benefit, even tempting us to read $\mathrm{v} 1$ as a true questioning of God and not just a rhetorical question. From $\mathrm{v} 7$ onward the presence of God as the object of Job's address is strongly marked, the "thou" appearing in vv 7, 8, 12, 14, 1621."14

\section{Disputation and Lament}

According to Clines as well, chapter 6-7 as a whole is a disputation speech. However, we find a prominent element in it, that is 'an appeal'. Clines calls 'appeal' as lament. Specifically, in chapter 7 , this lament is solely addressed to God and the style has much corresponding elements to the psalmic models of an appeal. ${ }^{15}$ Meanwhile, Roland E. 
Murphy has a different proposal. For him, chapter 6-7 as a whole is a lament. The prominent element of this lament is a disputation speech. ${ }^{16}$ In other words, Murphy sees it on the other way around. Anyway, both scholars simply point out that there is a lament in chapter 6-7. As we generally know, lament is found mostly in Psalms. Therefore, probably there is an indication that the author of Job knows very well a certain poetic style of Psalms referred to lament. Then, intentionally, he employs it within the book of Job with a different purpose. As going to be argued later in this paper, in the following section of this paper, the author wants to adapt the literary style of Psalm 8 as a message of protest or critique.

It is important as well to notice the function of those speeches, whether it is a disputation or a lament. Related to chapter 7, Clines explains the function of the speech distinctly. He says, "...the speech has a double focus. On the one hand, in its address to the friends, it offers them the opportunity of convincing Job that he does in fact deserve what is happening to him, and on the other, in its address to God, it calls upon God to desist from attacking him so that he may live out his few remaining days in comparative peace." 17

\section{PARODY AND GENRE}

Katharine J. Dell argues that the book of Job belongs to a genre, called 'parody'. This type of genre is a modern concept. It is not like other conventional classifications, such as lament, or even as thanksgiving speech. She, however, admits that it is still an improper genre to say.

Interestingly, she affirms that the book of Job is a 'parody' because there is a certain characteristic feature of the book. She states, "...a characteristic feature of Job is that it constantly misuses the forms it contains." ${ }^{18}$ What she means is the author deliberately misuses traditional forms from legal, cultic spheres in order to convey his scepticism or perhaps a critique. Dell gives a clarification regarding the word 'misuse'. For her, the word 'misuse' refers to "a traditional form being used with a different con- tent and context but being placed in a different context with a different function." ${ }^{19}$ In other words, the author misuses the text to create a certain 'ironic' or 'sceptical' effect.

As an uncommon concept in our biblical literary style, Dell argues that parody does not stand in itself. In order to exist, parody needs preexistent material (original material). Significantly, antithetical to its original is the key point that the parody generally makes. Therefore, parody tends to reshape perception of that original. She says, "the parody genre usually 'sends up' the original in some way, not necessarily in comic mode." ${ }^{20}$ Her understanding of parody is in fact based on the definition given by Dr. Johnson. She quotes him in saying, "parody is a kind of writing in which the words of an author or his thoughts are taken and by a slight change adapted to some new purpose." 21

Dell finds that in the book of Job, some speeches are generally intended to be to critique traditional positions held by the Job's friends in mocking or sarcastic tone. Nevertheless, parody is not always necessarily to be seen as negative. Dell refers to Will Kynes in saying that parody can be positive rather than simply critical or ironic or with negative purpose. ${ }^{22}$ Moreover, in order for the reader to appreciate a parody, that reader needs familiarity with the original that is being parodied. Dell clarifies her point by giving an example. Here is what she says. "...when it comes to the psalms for example, we can only fully appreciate a parody of either the form or content by knowing the original in reference to a form-critical type in some case or an actual psalm in others. Furthermore, parodies can generate further parodies so that can be a chain of parodies feeding off an original but also branching out into new thought domains..."23

Dell also observes that parody as a literary technique develops outside 'wisdom' and outside the influence of Egyptian literature (in which parody is not found). ${ }^{24}$ Parody usually stands at the end of a tradition. She points out to the book of Jonah as an example. She says, "The book of Jonah...was produced at a time when prophecy was on the wane. Prophecy is often seen to have failed 
and B. Vawter argues that Jonah is not only a failed prophet but has become for the author of the book 'almost a buffoon of prophecy'..." 25 In other words, Dell asserts that the book of Jonah stands at the end of 'prophecy' and provides a satirical critique of it. It is the same with the book of Job.

Furthermore, she underlines the word 'irony'. For her, irony as an important tool for conveying 'scepticism', is also fundamental to an understanding of Job. ${ }^{26}$ In her opinion, irony directed at one's own culture is a late development. How 'irony' works? Here is what she explains,

"At first the archetypes of a culture are full of power and give form to the world of a particular society. But these archetypes become hardened into a canon and eventually lose their 'depth dimension'. When this happens, irony develops and the creative author has to step outside the culture to use the old forms in new ways. For the author of Job who stood at the end of his own tradition, the time was ripe for such techniques." ${ }^{27}$

\section{JOB 7 AND PARODY}

\section{A Contradictory View}

As we commonly understand, in Psalm 8:5, the psalmist expresses awe at God's favor. God lifts up man from all creations. Consequently, man praises God's majesty. Job, however, turns this on its head. In Job 7, Job underlines God's constant attention to man, as the Psalmist does. Nevertheless, Job sees this as a negative thing. He feels that he cannot get away from God. He pleads God to leave him alone. Thus, there is a contradictory view between Psalm 8 and Job 7. Psalm 8 is a thanksgiving for God's concern for man's life, whereas Job 7:11-21 accuses God of being a "watcher of man" and Job longs for release. ${ }^{28}$ Furthermore, here is what Dell says, "...rather than seeing human beings as the apex of God's creative act, as the psalm does, Job rather sees humanity in more mundane terms as 'full of trouble'..." 29

Referring to Dell's definition of parody, we may apply it as well here. In Psalm 8, the form of verse 5 is filled with a new content, in a new context written in Job 7:17-18. Thus, this technique creates a parody of the original (Psalm 8:5-6). ${ }^{30}$ Here, the author wishes to convey that God is an oppressive presence for Job. That is the content. The author seems to express it through the mouth of Job and Job speaks of the words used familiarly in the Psalms to praise God. Job uses the form of Psalm 8 but what follows then is an opposite content of the original message of Psalm 8. Dell emphasizes that, "...parody can thus be seen as a valid classification for the literary techniques employed by biblical authors who are trying to make a protest on the level of form as well as content by using genre in a new way." 31

\section{Elements of Parody found in Job 7:17-19}

Now we are going to observe closely these three verses in relation to Psalm 8:5-6. There are several words in Job 7:17-19 that echo the language of Psalm 8:5-6.

Job 7:17 and Ps. 8:5

\begin{tabular}{|c|c|}
\hline \multicolumn{1}{|c|}{ Psalm 8:5 } & Job 7:17 \\
\hline $\begin{array}{l}{ }^{4} \text { what are human beings } \\
\text { that you are mindful of them, } \\
\text { mortals that you care for them? }\end{array}$ & $\begin{array}{l}{ }^{17} \text { What are human beings, } \\
\text { that you make so much of them, } \\
\text { that you set your mind on them, }\end{array}$ \\
\hline
\end{tabular}

Here, Job begins with a quotation of Psalm 8:5. He reechoes the language of Psalm 8:5, by saying [mâh-'énôš] (what are human beings?). Based on its hebrew grammar, what follows in the subordinate clause is a different verb. In Job 7:17, the verb is translated as 'make so much', yet Hebrew verb root (base form) used here is [gadal] in piel form, bearing a meaning, 'to save' or 'to extol'. ${ }^{32}$ Meanwhile in Psalm 8:5, the verb root is [zakar] that can be translated as 'to remember, or to be mindful'. ${ }^{33}$ Although 
those two verbs are not exactly the same, however Job's words are so similar that Job must have that Psalm in mind as he says. ${ }^{34}$ Clines says the same thing. For him, the verb [gadal] in Job 7:17 is modeled on a clear portrayal of human beings praised as the highest rank of creation mentioned in Psalm $8 .^{35}$

Another interesting word in Job 7:17 is 'to set [shiyth]'. According to Gray, this verb has a common idiom and meaning, "pay heed to, consider', found in Ex. 7:23, 1 Sam. 4:20, Psalm 48:14(13). ${ }^{36}$ Interestingly this verb is followed by $[l e \underline{b}]$ meaning 'heart'. In
Hebrew, the heart is the seat of cognition rather than affection. ${ }^{37}$ Thus, 'heart' is not the organ of affection, but of understanding.

From here, the parody begins. Job depicts before God his desolation in the manner of the psalmist. Job portrays his sufferings as in the long days to go, whereas the psalmist calls on God to remember his faithfulness. Job addresses God by shouting out, "what are human beings?" as the psalmist would shout. This shout is no longer about a constant concern of God for human beings but it is now about a constant trial and torment. ${ }^{38}$

Job 7:18

\begin{tabular}{|c|c|}
\hline Job 7:18 & Psalm 8:5 \\
\hline $\begin{array}{c}18 \text { visit them every morning, } \\
\text { test them every moment? }\end{array}$ & $\begin{array}{l}{ }^{4} \text { what are human beings } \\
\text { that you are mindful of them, } \\
\text { mortals that you care for them? }\end{array}$ \\
\hline
\end{tabular}

The parody centers on the hebrew verb [paqad] in Job 7:18, meaning 'to take special note of'. This verb may indicate a periodic 'stocktaking', which is the primary sense of the verb, which only secondarily means 'to visit'. ${ }^{39}$ According to Gibson, this verb is one of the Bible's loveliest words when the thought is of God drawing near with his aid and consolation. ${ }^{40}$ Gibson refers it to Exod. 4:31; Ruth 1:6; and Psalm 65:9. However, [paqad] has another use as well, particularly related to a military use. In this context, it is translated as 'to review or to muster troops'. Gibson compares it to 1 Sam 11:8. There, [paqad] can also means 'to number', 'to take a census of' the people for army service as we commonly find it in the book of Numbers. Gibson argues that perhaps in the context of military use, Job is thinking of. ${ }^{41}$ Job brings negative nuances to what he says after resembling his first colon with Psalm 8:5.
Besides, there is also another interesting expression in Job 7:18, namely, 'every morning'. According to Gray, this nouns is derived from a verb describing the flickering, that is, of an eyelid, and may be a metathetic cognate of Arab, bearing a meaning 'to tremble'. ${ }^{42}$ Combining those two expressions 'to visit' and 'every morning', Gibson gives us an interesting interpretation. He states,

"The psalmist looks at the starry heavens in wonder that the great God who made them should so condescend as to heap such honor upon puny mankind as he does. Job in his blasphemous parody (and it is splitting hairs to say that it is not) wonders that such a great God should attach such importance to men that he cannot put them out of his mind but has to hector them every day, every moment even, like a sergeant-major on the parade ground. Oh that he would avert his critical gaze just long enough for one poor soldier to clear his throat!" ${ }^{43}$

Job 7:19

\begin{tabular}{|c|c|}
\hline Job 7:19 & Psalm 8:6 \\
\hline $\begin{array}{c}19 \text { How long] will you not look away from me for a } \\
\text { while, } \\
\text { let me alone until I swallow my spittle? }\end{array}$ & $\begin{array}{c}5 \text { Yet you have made them } \\
\text { a little lower than God, } \\
\text { and crowned them with glory and honor. }\end{array}$ \\
\hline
\end{tabular}


In verse 19, Job indignantly asks 'how long' [kammāh] will God continue to direct upon him endlessly. In hebrew vocabulary, another meaning of [kammāh] is 'how much' (13.23), 'how often' (21.17), or 'how long' (Ps. 35.17). Furthermore, Gray notices a provoking phrase 'not looking away from me'. According to him, this expression is in the sense of overlooking, or averting one's gaze from, as in Isa. 22.4. ${ }^{44}$ Here, it seems that Job asks with despairing impatience how long it will be before God looks away from him. Gray observes as well that outside the Book of Job (where 10:20; 14:6 are parallels), such a wish is expressed only in Psalm 39:14. ${ }^{45}$ Nevertheless, in Psalm 39, the tone is more positive, because the psalmist refers to God as his hope.

Another fascinating expression is 'until I swallow my spittle'. It recalls an Arabic expression cited by Schultens, 'abli'n $n \hat{\imath}$ rîqi ('Let me swallow my spittle', i.e. 'Leave me a moment'). ${ }^{46}$ Clines seems to understand that the vivid phrase 'let me alone until I swallow my spittle' is a strong message of Job's appeal. This phrase represents powerfully Job's sense of the cruelty of God's assaults upon him. ${ }^{47}$

\section{CONCLUSION}

The book of $J o b$ is unique. Its uniqueness lies in its uncommon genre, namely parody, as Katherine J. Dell has suggested. Chapter 7:17-19 is one of examples to understand the concept of parody in the book of Job. As we understand from the previous explanation, parody never stands alone. Parody

\section{ENDNOTES}

1 Leo G. Perdue, Wisdom in Revolt: Metaphorical Theology in the Book of Job, Bible and Literature Series 29 (Sheffield: The Almond Press, 1991) 121.

2 "A colon is a single line of poetry, either as s semiindependent unit or as part of a larger strophe... A strophe is a verse-unit of one or more cola, considered as part of the higher unit termed the stanza." W. G. E. Watson, Classical Hebrew Poetry. A Guide to Its Techniques, JSOT 026 (Sheffield: JSOT Press, 1984) 12-13.

3 John Gray and David J.A. Clines, The Book of Job, The Text of the Hebrew Bible 1 (Sheffield: Sheffield Phoenix Press, 2010) 28. needs a prematerial (original material) to exist. Without its original material, the reader would not be able to appreciate parody. Here, in Job 7:17-19, it is suggested that its original material is Psalm 8:5-6. There is an echo of the language of Psalm 8:5-6 found in Job 7:17-19.

Regarding the intention of the author, we may underline that the book of Job is a "wisdom in revolt" as Perdue would argue. It means that generally the book of Job stand to give a critique of a sceptical thought to the conventional wisdom as what can be found in Proverbs and Psalms. Particularly in Job 7:17-19, we see clearly how the author creates an irony of Psalm 8. The author deliberately steps outside literary conventions to make a protest. The inadequacy of the traditional ethic of wisdom, already felt in this Psalm 8, now is exposed ironically by the author. A message of humbly gratitude in Psalm 8 becomes a message of weariness and frustration. It seems that the author wants to deconstruct people's reliance on common traditional wisdom as a way of life. The author encourages readers to bravely question the predominating wisdom tradition that focusing on the mechanical relation between good deeds and blessings. The main basis of author's concern is simply on the more realistic experience of human suffering. The message is that human suffering in fact can not be answered mechanically by traditional wisdom (as depicted through the portrayal of Job's three friends). That is the point that probably the author wants to emphasize through chapter $7: 17-19 .^{* * *}$
Gray and Clines, The Book of Job, 26.

5 Gray and Clines, The Book of Job, 28.

6 R. N. Whybray, M. Barker, and K. J. Dell, Wisdom: The Collected Articles of Norman Whybray, SOTS (Aldershot: Ashgate, 2005) 208.

7 Gray and Clines, The Book of Job, 167-168.

8 Gray and Clines, The Book of Job., 168.

9 Gray and Clines, The Book of Job, 167-168.

10 Perdue, Wisdom in Revolt: Metaphorical Theology in the Book of Job, 121.

11 Perdue, Wisdom in Revolt:, 125.

12 Perdue, Wisdom in Revolt:, 121.

13 D. J. A. Clines, Job 1-20, WBC 17 (Dallas, Tex.: Word, Incorporated, 2002) 167.

14 D. J. A. Clines, Job 1-20, 167 
15 D. J. A. Clines, Job 1-20, 168.

16 D. J. A. Clines, Job 1-20, 168.

17 D. J. A. Clines, Job 1-20, 168.

18 K. J. Dell, The Book of Job as Sceptical Literature, BZAW 197 (Berlin: De Gruyter, 1991), 110.

19 K. J. Dell, The Book of Job as Sceptical Literature, 110.

20 K. J. Dell, Job: Where Shall Wisdom Be Found?, Phoenix Guides to the Old Testament (Sheffield: Sheffield Phoenix Press, 2013) 34.

21 Dell, Job: Where Shall Wisdom Be Found?, 34.

22 Dell, Job: Where Shall Wisdom Be Found?, 34.

23 Dell, Job: Where Shall Wisdom Be Found?, 34.

Dell, The Book of Job as Sceptical Literature, 153.

25 Dell, The Book of Job as Sceptical Literature, 154.

Dell, The Book of Job as Sceptical Literature, 157.

Dell, The Book of Job as Sceptical Literature, 157.

Dell, Job: Where Shall Wisdom Be Found?, 35

Dell, Job: Where Shall Wisdom Be Found?, 35

Dell, Job: Where Shall Wisdom Be Found?, 35.

31 Dell, The Book of Job as Sceptical Literature., 157.

32 W. L. Holladay, L. H. Koehler, and W. Baumgartner, A Concise Hebrew and Aramaic Lexicon of the Old Testament (Leiden: Brill, 1971) 56.

33 Holladay, Koehler, and Baumgartner, A Concise Hebrew and Aramaic Lexicon of the Old Testament, 89.

34 J. C. L. Gibson, Job, OT Daily Study Bible (Philadelphia: The Westminster Press, 1985), 67.

35 Clines, Word Biblical Commentary., 192.

36 S. R. Driver and G. B. Gray, A Critical and Exegetical Commentary on the Book of Job (Edinburgh: T \& $\mathrm{T}$ Clark, 1921) 73.

37 Gray and Clines, The Book of Job, 181.

38 J. H. Eaton, Job, JSOT 005 (Sheffield: JSOT Press, 1985) 5 .

39 Gray and Clines, The Book of Job, 166.

40 Gibson, Job, 67.

41 Gibson, Job, 67.

42 Gray and Clines, The Book of Job, 181.

43 Gibson, Job, 67.

44 Gray and Clines, The Book of Job., 181.

45 Clines, Word Biblical Commentary, 193.

46 Gray and Clines, The Book of Job, 181.

47 Clines, Word Biblical Commentary, 193.

\section{BIBLIOGRAPHY}

Clines, David J. A. Job 1-20. WBC 17. Dallas, Tex.: Word, Incorporated, 2002.
Dell, Katharine J. Job: Where Shall Wisdom Be Found? Phoenix Guides to the Old Testament. Sheffield: Sheffield Phoenix Press, 2013.

. The Book of Job as Sceptical Literature. BZAW 197. Berlin: De Gruyter, 1991.

Driver, Samuel Rolles, and George Buchanan Gray. A Critical and Exegetical Commentary on the Book of Job. ICC. Edinburgh: T \& T Clark, 1921.

Eaton, John H. Job. JSOT 005. Sheffield: JSOT Press, 1985.

Gibson, John Clark Love. Job. OT Daily Study Bible. Philadelphia: The Westminster Press, 1985.

Gray, John, and David J.A. Clines. The Book of Job. The text of the Hebrew Bible 1 . Sheffield: Sheffield Phoenix Press, 2010.

Holladay, William Lee, Ludwig Hugo Koehler, and Walter Baumgartner. A Concise Hebrew and Aramaic Lexicon of the Old Testament. Leiden: Brill, 1971.

Perdue, Leo G. Wisdom in Revolt: Metaphorical Theology in the Book of Job. Bible and Literature Series 29. Sheffield: The Almond Press, 1991.

Watson, W. G. E. Classical Hebrew Poetry. A Guide to Its Techniques. JSOT 026. Sheffield: JSOT Press, 1984.

Whybray, Roger Norman, Margaret Barker, and Katharine J. Dell. Wisdom: The Collected Articles of Norman Whybray. SOTS. Aldershot: Ashgate, 2005. 